\title{
Organoleptic testing of coconut midrib ash and alcohol as preservatives of insect specimens
}

\author{
Hasan Maulana ${ }^{1,2}$, Yossa Istiadi ${ }^{1}$, and Dolly Priatna ${ }^{1}$
}

${ }^{1}$ Graduate School of Environmental Management, Pakuan University, Jl. Pakuan Kotak Pos 452, Bogor 16129, Indonesia

${ }^{2}$ Bogor Zoological Museum, The Indonesian Sciences Institute, Jl. Ir. H. Juanda No. 9, Bogor 16122, Indonesia

Corresponding author: Hasan Maulana, maulanamaul123q@gmail.com

\begin{abstract}
This study uses a Completely Randomized Design experimental method (CRD) consisting of three treatments with a range of 5 days, 10 days and 15 days, with each treatment uses three insect specimens. The treatments in this study were; P1 (200 $\mathrm{mg}$ ash $+200 \mathrm{ml}$ distilled water), P2 (70\% alcohol), and P0 (control). To observe the changes in texture, aroma and color in the inspect specimens, 50 panelists were engaged, who were aged between 17-30 years, that were not color blind and/or reporting any ill health at the time of sampling. Panelists observed the specimens for texture, aroma and color. Resulting data was analyzed using $t$ test, frequency tabulation, histogram data and normality test. The texture testing treatments yielded $t_{\text {cou }}$ $=0.02521(\mathrm{p}>0.05)$ showing no significance between the coconut midrib ash and alcohol preserved samples, with the $\mathrm{H}_{\mathrm{o}}$ accepted, so there is no difference in the texture of insect specimens preserved in either coconut midrib ash or alcohol. The aroma test resulted in $\mathrm{t}_{\text {count }}=0.00908(\mathrm{p}>0.05)$ showing again there was no significant difference between insect specimens preserved in coconut midrib ash and alcohol. Thus, the $\mathrm{H}_{\mathrm{o}}$ can be accepted, with no difference in the aroma of insect specimens preserved in coconut midrib ash or with alcohol. The color test resulted in a $t_{\text {count }}=0.05635$ ( $\left.\mathrm{p}>0.05\right)$, giving a insignificant result between insect specimens preserved in coconut midrib ash or alcohol. Thus, the $\mathrm{H}_{\mathrm{o}}$ can be accepted, and there is no difference in color of insect specimens preserved with coconut midrib ash or those preserved with alcohol. From the overall results and analysis, we can conclude there is no difference in the quality insect specimens preserved either by coconut midrib ash and alcohol for a maximum 15 days.
\end{abstract}

\begin{abstract}
ABSTRAK
Penelitian ini menggunakan metode eksperimen rancangan acak lengkap (RAL) yang terdiri dari tiga perlakuan dengan kisaran lama waktu 5 hari, 10 hari, dan 15 hari. Setiap satuan percobaan menggunakan tiga spesimen serangga, perlakuan dalam penelitian ini meliputi P1 (200 mg abu $+200 \mathrm{ml}$ aquades), P2 (alkohol 70\%), dan P0 (kontrol). Parameter yang diamati mengenai tekstur, aroma dan warna. Untuk mengamati perubahan tekstur, aroma dan warna yang terjadi, dilakukan oleh 50 orang panelis yang berusia antara 17-30 tahun dengan kriteria tidak buta warna dan tidak sedang dalam keadaan sakit. Data yang diperoleh dianalisis dengan menggunakan uji t, tabulasi frekuensi, data histogram dan uji normalitas. Berdasarkan hasil penelitian, pengujian tekstur menghasilkan nilai $\mathrm{t}_{\text {hitung }}=0,02521(\mathrm{p}>0,05)$, diperoleh hasil yang tidak berbeda secara signifikan antara perlakuan dengan abu pelepah kelapa dan alkohol terhadap tekstur spesimen serangga. Dengan demikian dapat disimpulkan bahwa tidak terdapat perbedaan tekstur spesimen serangga yang diawetkan dengan abu pelepah kelapa dengan yang diawetkan dengan alkohol. Pengujian aroma menghasilkan nilai $t_{\text {hitung }}=0,00908(\mathrm{p}>0,05)$, diperoleh hasil tidak berbeda secara signifikan antara perlakuan dengan abu pelepah kelapa dan perlakuan dengan alkohol. Dengan demikian dapat disimpulkan bahwa tidak terdapat perbedaan warna spesimen serangga antara yang diawetkan dengan abu pelepah kelapa dengan yang diawetkan dengan alkohol. Dari hasil pengamatan dapat disimpulkan bahwa tidak ada perbedaan kualitas antara specimen serangga yang diawetkan dengan abu pelepah kelapa dengan yang diawertkan dengan alcohol dalam waktu maksimum 15 hari.
\end{abstract}

Keywords: Alcohol, coconut midrib ash, insect preservative.t

\section{INTRODUGTION}

Organoleptic testing or sensory evaluation is defined as the scientific assessment of characteristics material using the senses of sight, taste, smell, touch and hearing, with sensory reaction recorded.

According to research by Suharna \& Rahayu (2000), despite using alcohol in high concentration in sample preservation growth of the fungus Monascus sp may still occur. The source of this contamination can come from

Submitted 15 March 2020; Accepted 22 September 2020. the specimen, be airborne or from the preserving alcohol which may have been contaminated with fungus.

When considering these potential negative effects from using alcohol as a sample preservative, it is necessary to look for alternatives that are more effective preservatives and safer. These may include natural ingredients such as coconut midrib waste, which when burnt gives ash. This ash has not been used much except for washing dishes and other kitchen utensils in 
the villages. According to Abdul (2010), coconut midrib ash contains Magnesium $(\mathrm{Mg})$ and Potassium $(\mathrm{K})$ which forms chemical salts; $\mathrm{MgCl}_{2}$ (Magnesium Chloride) and $\mathrm{KCl}$ (Potassium Chloride). Each element has anti-microbial properties.

The purpose of organoleptic testing is to determine the differences between the texture, aroma and color of insect specimens preserved with coconut midrib ash against those preserved in alcohol.

Rahmatulloh et al. (2017), used organoleptic tests to determine the variation of skin texture, hair, and aroma of taxidermied mice after 45 days, having been treated with various concentrations of coconut midribs ash and borax. Results reported in this study included:

\section{Skin Texture}

The combination of coconut midrib ash and borax gave slightly better skin texture on the samples. The treatment given relatively has the same effect on the skin texture of mice after preserving for 45 days. This is due to the content of $\mathrm{MgCl}_{2}$ and $\mathrm{KCl}$ contained in coconut midribs as an anti-microbial.

\section{Hair Texture}

The application of borax was observed to have a slightly better texture of hair, which relatively has the same effect on the texture of the mice's hair after preserving for 45 days.

\section{Aroma}

The combination of coconut midrib ash and borax were observed to have a slightly nicer roma (no foul smell), after preserving for 45 days. This was due to the salt content found in coconut midribs, which has anti-microbial properties and borax ash which acts as an antiseptic, which kills or inhibit the growth of microorganisms found in animal tissue.

\section{Color}

Negara (2016) argue that the color is primary sensory response that observes will use in organoleptic testing.

Based on the description of the theories above, the organoleptic sensing approach can be replicated when determining viable natural alterative to preserving insect specimens.

\section{METHODS}

This study employed an experimental method. The design employed was a Completely Randomized Design (GRD) with one factor consisting of 3 treatments, namely:

$\mathrm{P}_{1}=$ Preservation for 5 days, 10 days and 15 days.

$\mathrm{P}_{2}=$ Preservation for 5 days, 10 days and 15 days.

$\mathrm{P}_{0}=$ Preservation for 5 days, 10 days and 15 days.

\section{Research Procedure}

\section{Preparation Stag}

In the first stage, 20 pieces of coconut midribs harvested and laid out in the sun to dry. After the coconut midribs were dried, they are burnt to produce ash used for preparing the specimens.

\section{Production Stage}

$200 \mathrm{mg}$ of coconut midrib ash was to create a treatment, mixed with $200 \mathrm{ml}$ of distilled water, and stirred thoroughly, and allowed to stand for 15 minutes. After 15 minutes, each treatment of coconut midrib ash water was filtered and decanted into a sterilized bottle.

\section{Preservation Stage}

9 selected insect specimens were anesthetized using Chloroform. For the coconut ash treatment - insect needle containing coconut ash treatment was injected into the abdomen of the insect specimen until it is evenly spread throughout its body. Researchers manipulated the shape of the wing and leg models with tweezers, to give the desired shape. Once in place, the desired shape was locked using a pin. Specimens were also treated with camphor to deter insect predation as they dried naturally. Specimens were preserved either in coconut midrib ash or $70 \%$ alcohol, for a period of 5 days, 10 days or 15 days.

\section{Organoleptic Testing}

Organoleptic testing was employed to determine the preservation of insect specimens. Respondents used their senses to determine the texture, aroma and color of a given insect specimen. Different respondents were invited to observe the specimens at 5, 10 and 15 days. Organoleptic testing for specimen texture was carried out by respondents observing samples using a magnifying glass or by directly smelling or using sense of touch. The organoleptic test for aroma of a specimen was carried out using the respondents sense of smell to determine the level or odor given off by a specimen. The scale used for textures is in the form of ten hedonic scales, namely 1 (very many holes in the sample) up to 10 (whole intact), Aroma is 1 (very foul odor) to 10 (Odorless), while for color 1 (very faded) to with 10 (fixed). For quality of colour of a specimen, each respondent used the sense of vision. Each of the senses was used to compare the preserved insect specimens against living specimens to determine the quality of preservation.

The number of respondents involved the organoleptic testing were 50 people. Organoleptic tests were carried out on museum visitors between the ages of 17-30 years, with respondents qualifying to participants that were neither color blind or not ill.

\section{Data Collection Techniques}

In this stage of research, data was obtained and recorded using a questionnaire technique. The insect preservation organoleptic or hedonic tests and results were calculated using $\mathrm{t}$ tests, frequency distribution, histogram data and normality tests. 


\section{RESULTS}

\section{Texture}

The results of the texture observations can be seen in Figure 1. The greatest organoleptic value was found in treatment 2 with a mean value of 27.44. Followed by treatment 1 - coconut midrib ash which had a mean value of 27.42, and the smallest result was the control treatment with a mean value of 14.10 .

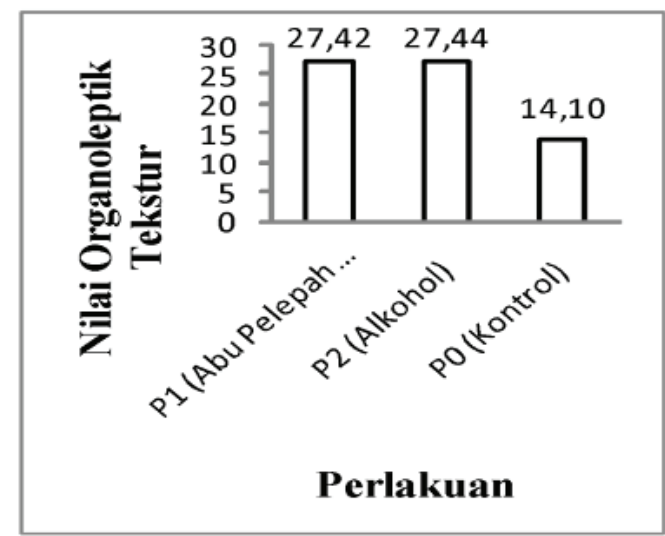

Figure 1. Organoleptic scores of texture.

\section{Aroma}

The results of the aroma observations can be seen in Figure 2. The greatest organoleptic value was found in treatment 2 (alcohol) with a mean value of 22.50. Then followed by treatment 1 ( coconut midrib ash) with mean value of 22.48, and the lowest result was recorded for the control treatment with a mean value of 12.70 .

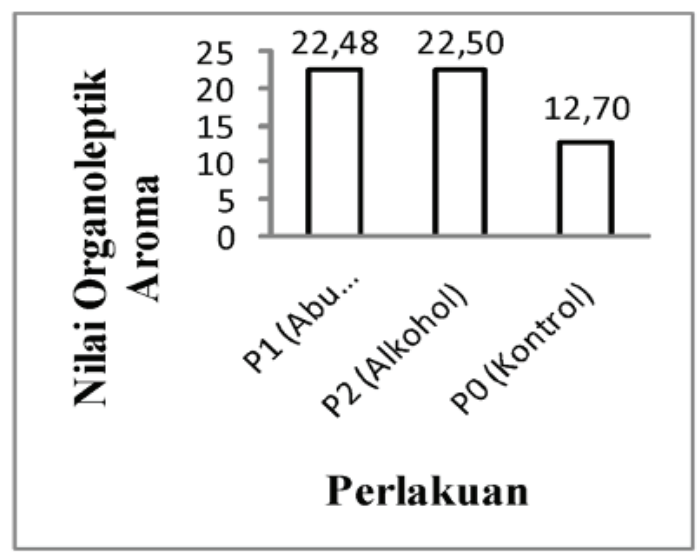

Figure 2. Organoleptic scores of aroma.

\section{Color}

The results of the color observation can be seen in Figure 3. The greatest organoleptic value was found in treatment 2 (alcohol) with a mean value of 22.52 . Treatment 1 (coconut midrib ash) recorded an average value of 22.36, while the lowest value was recorded in the control treatment with a mean value of 12.88 .

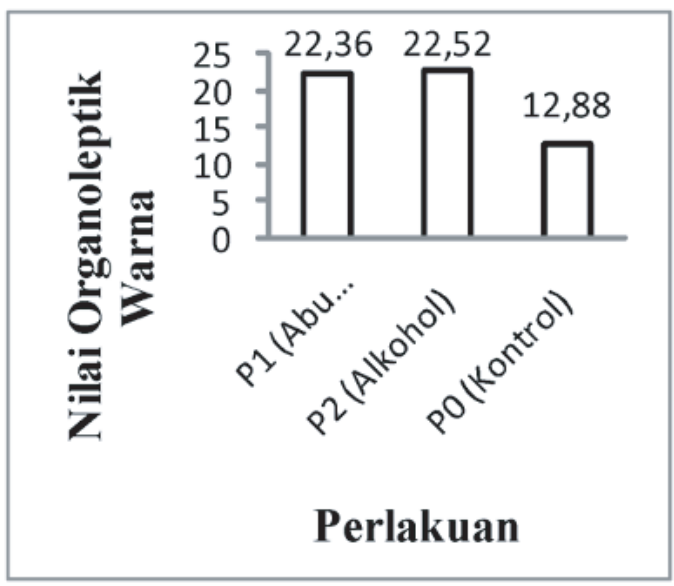

Figure 3. Organoleptic scores of color.

\section{DISGUSSION}

Based on the results of the study, the texture test resulted in a value of $t_{\text {count }}=0.02521(\mathrm{p}>0.05)$, giving a insignificant result between coconut midrib ash and alcohol. It can be concluded that the $\mathrm{H}$ is accepted and there is no difference in the texture of insect specimens preserved with coconut midrib ash or those preserved with alcohol.

Test the aroma of the value of $t_{\text {count }}=0.00908(\mathrm{p}>$ 0.05), determined a insignificant results between coconut midrib ash and alcohol. Thus, it can be concluded that $\mathrm{H}_{\mathrm{o}}$ is accepted, It can concluded there is no difference in the aroma of insect specimens preserved with coconut midrib ash and those preserved with alcohol.

Testing the color value of $\mathrm{t}_{\text {count }}=0.05635(\mathrm{p}>0.05)$, determined a insignificant results between coconut midrib ash and alcohol. It can be concluded that $\mathrm{H}_{\mathrm{o}}$ is accepted, so there is no difference in the aroma of insect specimens preserved with coconut midrib ash and those preserved with alcohol.

In Rahmatulloh et al. (2017), coconut midrib ash and borax, (P3) showed a slightly better skin texture with mean of 2,887 , followed by P1 $(2,875)$ and P2 $(2,850)$. Testing the skin texture obtained $\mathrm{F}_{\text {count }}$ value $=0.025$ ( $>$ > 0.05), this showed all treatments had relatively the same effect on the skin texture of mice after preserving for 45 days of preservation. The $\mathrm{H}_{\circ}$ is accepted, showing there is no difference between the texture of the skin preserved with coconut midrib ash or the preserved with borax.

The results of the study found to preserve the texture of hair the administration of $100 \%$ borax (P1) showed a mean of 2.96, followed by the administration of $50 \%$ borax (P3) with an a mean value of 2.93 and the application of ash $100 \%$ coconut midrib (P2) a mean value of 2.90. Testing the texture of hair gave an $\mathrm{F}_{\text {count }}$ value $=0.105(\mathrm{p}>0.05)$, showing that all treatments have relatively the same effect on the texture of mice hair after preserving for 45 days. It can be concluded the $\mathrm{H}_{\mathrm{o}}$ can be accepted, so there is no difference in the 
texture of the hair preserved with coconut midrib ash and those preserved with borax.

The combination of coconut midrib ash and borax (P3) showed a slightly better aroma with a mean value of 2.937, followed by giving P2 (2.925) and P1 (2.912). Testing the aroma obtained $\mathrm{F}_{\text {count }}$ value $=0.017(\mathrm{p}>$ $0.05)$, found all treatments had relatively the same effect on the aroma of mice after 45 days of preservation. It can be concluded that $\mathrm{H}_{\mathrm{o}}$ is accepted, then there is no difference in the aroma preserved with coconut midrib ash and those preserved with borax.

According to Pakaya et al. (2014) the use of star fruit (Averrhoa bilimbi L.) as a natural preservative, tested in concentration (three levels: $\mathrm{C} 1=100 \mathrm{mg} / \mathrm{ml}, \mathrm{C} 2=$ $200 \mathrm{mg} / \mathrm{ml}$ and $\mathrm{C} 3=300 \mathrm{mg} / \mathrm{ml}$ ) while the second treatment $(\mathrm{T})$ is the duration of storage (Three Levels: $\mathrm{T} 1=0$ days, $\mathrm{T} 2=15$ days and $\mathrm{T} 3=30$ days). The results showed the presence of bacteria concentrations of $100 \mathrm{mg} / \mathrm{ml}, 200 \mathrm{mg} / \mathrm{ml}$ and $300 \mathrm{mg} \mathrm{ml}$ of starfruit (Averrhoa bilimbi L.) solution significantly inhibited bacterial growth $(\mathrm{p}<0.01)$. For the treatment of storage time 0 days, 15 days and 30 days significantly affected the growth of bacteria $(p<0.01)$, meaning that the longer the dried anchovies, were soaked in star fruit solution, and the higher the concentration the smaller the bacterial growth. Thus, it can be concluded that $\mathrm{H} 1$ is accepted, so there are differences in influence between treatments.

\section{CONCLUSION}

1. The greatest organoleptic value for texture was for treatment 2 with alcohol with a mean value of 27.44. Then followed by treatment 1 with the administration of coconut midrib ash with a mean value of 27.42, and the smallest result in the control treatment with a mean value of 14.10 .

2. The greatest organoleptic value of aroma was treatment 2 was the alcohol with a mean value of 27.50. Followed by treatment 1 with the administration of coconut midrib ash with a mean value of 22.48, and the lowest result was the control treatment with a mean value of 12.70 .

3. The largest color organoleptic value in treatment 2 with the administration of alcohol with a mean value of 22.52. Then followed by treatment 1 with the administration of coconut midrib ash with a mean value of 22.36, and the lowest result found in the control treatment with a mean value of 12.88 .

\section{AGKNOWLEDGMENTS}

Authors wish to extend his gratitude to the Head of Bogor Zoological Museum for willingness to support and granting permission in conducting this research.

\section{REFERENGES}

Abdul, R. (2010). Uji organoleptik dan keawetan ikan teri asin hasil pengasinan menggunakan abu pelepah kelapa. Skripsi. Universitas Muhammadiyah Surakarta, Surakarta.

Rahmatulloh, R., Effendi, M. \& Triastinurmiatiningsih, T. (2017). Pemanfaatan abu pelepah kelapa sebagai pengganti boraks dalam teknik taksidermi Mencit (Mus musculus). Furnal Online Mahasiswa Bidang Biologi (2)(2): 1-7.

Pakaya, Y. T., Olii, A. H. \& Nursinar, S. (2014). Pemanfaatan Belimbing Wuluh sebagai pengawet alami pada ikan teri asin kering. Furnal Ilmiah Perikanan dan Kelautan (II)(2): 93-96.

Suharna, N. \& Rahayu, R. D. (2000). Efektivitas alkohol dan campurannya dengan formalin sebagai bahan pengawet spesimen binatang untuk udang. Furnal Berita Biologi (5)(1): 61-67. 